e-mail: serhii.kuryliuk@pu.if.ua

https://orcid.org/0000-0003-1588-5756

Мельник Андрій - викладач, Прикарпатський Melnyk Andrii - Lecturer, Precarpathian Faculty of факультет Національної академії внутрішніх справ the National Academy of Internal Affairs (Ivano(Івано-Франківськ, Україна) Frankivsk, Ukraine)

https://orcid.org/0000-0003-1588-5756

Мельник Олена - викладач, Івано-Франківський фаховий коледж ДВНЗ "Прикарпатський національний університет імені Василя Стефаника" (Івано-Франківськ, Україна)

e-mail: serhii.kuryliuk@pu.if.ua

https://orcid.org/0000-0003-1588-5756

УДК 796. 378.093

doi: 10.15330/fcult.36.101-107

Ігор Випасняк, Богдан Мицкан, Тетяна Мицкан, Лілія Войчищин

\title{
КОРЕКЦІЯ ПОРУШЕНЬ СКЛЕПННЧАСТОГО АПАРАТУ СТОПИ У МОЛОДШИХ ШКОЛЯРІВ ЗАСОБАМИ ТАЕКВОН-ДО
}

Мета. Виявити вплив засобів таеквон-до на корекцію плоскостопості у молодших школярів. Методи. До педагогічного експерименту, за згодою батьків, було залучено 25 дітей чоловічої статі віком 7-10 років, з I-ІІ ступенем плоскостопості, з числа учнів 2-4 класів закладів середньої освіти м. Івано-Франківська. Секиійні заняття проводилися під керівництвом тренера-інструктора з таеквон-до тричі на тиждень протягом 9-ти місяиів, тривалістю 60 хвилин. Максимальна ЧСС не перевищувала 140 уд/хв. Для дослідження стопи використовували метод Е.Г. Мартиросова [4], який передбачає зняття відбитків підошовної поверхні стоп (плантограми). Результати. Виокремлюють наступні фактори, які впливають на розвиток плоскостопості: недорозвинені м'язи стопи, слабкість м'язово-зв'язкового апарату, надмірні фізичні навантаження, надлишкова вага, тривала гіпокінезія, неправильно підібране взуття, косолапість, ікс-подібна форма ніг, травми стопи та надп'ятковогомілкового суглобу, а також генетично детермінована форма стопи. Розробка нових $і$ вдосконалення існуючих засобів збереження соматичного здоров'я дітей молодшого шкільного віку та відновлення їх організму при різних порушеннях є одним із важливих завдань фізичної культури. В иъьому контексті була розроблена інноваційна програма для дітей молодшого шкільного віку з порушеннями склепінчастого апарату стопи. В підготовчій частині заняття, окрім гімнастичних вправ для різних груп м'язів, використовували комплекс суглобової гімнастики з метою підготовки організму молодших школярів до виконання технічних елементів таеквон-до. В основній частині заняття акиент робився на вивчення й удосконалення базових ударів ногами, а в заключній використовували релаксачійні вправи, самомасаж, дихальну гімнастику. Аналіз плантограм зроблених до початку $і$ в кінці педагогічного експерименту дозволив встановити вірогідне покращення коефіцієнту $K$, пяточного кута $i$ кутів біля першого $i$ n'ятого пальців, щуо $\epsilon$ свідченням повної корекиії плоскостопості. Висновок. Отже встановлено, щуо комплексне застосування засобів таеквон-до і суглобової гімнастики забезпечує нормалізацію склепінчастого апарату стопи у дітей молодшого шкільного віку з I-II ступенем плоскостопості.

Ключові слова: молодші школярі, плоскостопість, таеквондо.

Aim. Identify the effect of taekwondo on the correction of flat feet in younger students. Methods. With the consent of parents, 25 male children aged 7-10 years, with I-II degree of flat feet, from among students of 2-4 grades of secondary schools in Ivano-Frankivsk were involved in the pedagogical experiment. Sectional classes were conducted under the guidance of a taekwondo coach up to three times a week for 9 months, lasting 60 minutes. The maximum heart rate did not exceed 140 beats / min. To study the foot used the method of Martirosov EG [4], which involves taking footprints of the plantar surface of the feet (plantogram). Results. There are the following factors that affect the development of flat feet: underdeveloped foot muscles, weakness of the musculoskeletal system, excessive exercise, overweight, prolonged hypokinesia, improperly selected shoes, clubfoot, X-shaped legs, foot injuries and ankle joint, as well as genetically determined shape of the foot. The development of new and improvement of existing means of maintaining the physical health of children of primary school age and the recovery of their bodies in various disorders is one of the important tasks of physical culture. In this context, an innovative program was developed for children of primary school age with disorders of the arch of the foot. In the preparatory part of the lesson, in addition to gymnastic exercises for different 
muscle groups, a set of joint gymnastics was used to prepare the body of younger students to perform the technical elements of taekwondo. In the main part of the lesson the emphasis was on the study and improvement of basic kicks, and in the final part they used relaxation exercises, self-massage, breathing exercises. Analysis of plantograms made before and at the end of the pedagogical experiment revealed a probable improvement in the coefficient $K$, heel angle and angles near the first and fifth fingers, which is evidence of complete correction of flat feet. Conclusion. Thus, it is established that the complex use of taekwondo and joint gymnastics provides normalization of the arch of the foot in children of primary school age with I-II degree of flat feet.

Keywords: junior schoolchildren, flat feet, taekwondo.

Постановка проблеми й аналіз результатів останніх досліджень. За даними підтвердженими у МО3 України [2, 10] загальна захворюваність дітей у віці від 1 до 14 років 3 кожним роком збільшується. Проблема збереження і зміцнення соматичного здоров’я дітей була актуальною в усі часи і залишається такою сьогодні [10]. При цьому, одним з комплексних показників соматичного здоров'я дитини є стан склепінчастого апарату стопи $[1,2,3,5,6,11]$. За останні роки спостерігається зростання інтересу до використанням нетрадиційних вправ оздоровчої гімнастики у фізичній культурі шкільної молоді. Однак, незважаючи на їх позитивний вплив на організм дітей молодшого шкільного віку, використання їх в якості ефективних засобів щодо корекції плоскостопості все ще не знайшло свого належного застосування.

Мета дослідження - виявити вплив засобів таеквон-до на корекцію гнучкої плоскостопості у молодших школярів.

Методи.До педагогічного експерименту, за згодою батьків, було залучено 25 дітей чоловічої статі віком 7-10 років, з I-II ступенем плоскостопості, з числа учнів 2-4 класів закладів середньої освіти м. Івано-Франківська. Для дослідження стопи використовували метод Е.Г. Мартиросова [4], який передбачає зняття відбитків підошовної поверхні стоп (плантограми).

Оцінку плантограм проводили за показниками поздовжньої плоскостопості. Поздовжню плоскостопість характеризують наступні показники: коефіцієнт К, який визначає стан середнього відділу склепіння стопи (2.6): $\mathrm{K}=\mathrm{x} / \mathrm{y}$ (2.6), де $\mathrm{x}$ - ширина зафарбованої частини відбитка по лінії $\mathrm{UU}^{\prime}, \mathrm{y}$ - ширина зовнішньої частини поздовжнього склепіння стопи. При К від 0 до 0,5 - стопу вважали склепистою, при К від 0,51 до 1,10 - 3 нормальним склепінням, при К від 1,11 до 1,20 - 3 пониженим склепінням, при К від 1,21 до 1,30 - I ступінь плоскостопості, при К від 1,31 до 1,5 - II ступінь плоскостопості, при К від 1,5 і більше - III ступінь плоскостопості. Як відомо, п'ятковий кут $\mathrm{HC}^{\prime}$ К, визначає стан заднього відділу поздовжнього склепіння стопи. Якщо кут НС'К більший або дорівнює 5, стан стопи у нормі, якщо кут НС'К менше 5 - стопа плоска. Довжину переднього та заднього відділів, оцінювали за проміжками, які відсікають лінії WW' та UU'. Якщо ці відділи видовжені, значить стопа плоска, навіть при нормальному стані середнього відділу. Таким чином, для плантограми при вираженій поздовжній плоскостопості характерне збільшення ширини середнього відділу стопи, зменшення п'яткового кута, видовження переднього та заднього відділів. Ці показники можуть спостерігатися окремо та комбіновано. Стан переднього відділу стопи характеризують такі показники: кут при I пальці (кут NAP), якщо кут NAP менше $18^{0}$, передній відділ стопи в нормі; якщо кут NAP більший або дорівнює $18^{0}$ - поперечне розпластування; кут при V пальці (кут QBR), якщо кут QBR менше за $12^{0}$, передній відділ стопи в нормі, а якщо кут QBR більший або дорівнює $12^{0}$ - поперечне розпластування.

Для виявлення різниці між досліджуваними групами, застосовувався критерій Стьюдента.

Результати. Причини відхилень у будові опорно-рухового апарата дітей молодшого шкільного віку найрізноманітніші. Дослідники пояснюють цей феномен багатьма факторами: від неправильної постановки нижніх кінцівок при стоянні і сидінні до 
генетичних чинників. Ранній появі дефектів склепінчастого апарату стопи сприяє недостатня увага до процесів росту і розвитку дитини з боку батьків і педагогів $[7,8]$.

Причин виникнення плоскостопості багато. Дослідники виокремлюють наступні фактори, які впливають на розвиток плоскостопості: недорозвинені м'язи стопи, слабкість м'язово-зв'язкового апарату, надмірні фізичні навантаження, надлишкова вага, тривала гіпокінезія, неправильно підібране взуття, косолапість, ікс-подібна форма ніг, травми стопи та надп'ятковогомілкового суглобу, а також генетично детермінована форма стопи $[1,5,6,8$ ]. Як наслідок, порушується правильне співвідношення сил в біокінематичній парі «хребет-склепінчастий апарат стопи».

Розробка нових і вдосконалення існуючих засобів збереження соматичного здоров'я дітей молодшого шкільного віку та відновлення їх організму при різних порушеннях є одним із важливих завдань фізичної культури. В цьому контексті була розроблена інноваційна програма для дітей молодшого шкільного віку 3 порушеннями склепінчастого апарату стопи.

Як відомо, програма - це цілісна впорядкована сукупність валідних та ефективних засобів, методів та прийомів, що забезпечують досягнення запланованої цілі [10]. До загальних компонентів комплексної програми корекції плоскостопості у дітей молодшого шкільного віку ми віднесли мету, завдання та принципи. Метою програми була нормалізація опорно-ресорних властивостей стопи. Щодо завдань, то вони були наступними: поліпшення обмінних процесів шляхом посилення крово- і лімфообігу в нижніх кінцівках, посилення диференціації зв'язкового апарату й скелетних м'язів стопи і гомілки, удосконалення фізичних здібностей та рухових навиків. Реалізацію цих завдань забезпечували дотримання таких правил: активною та свідомою участю дітей та батьків в реалізації програми; дотримання систематичності та безперервності занять; доступності, поступовості і варіативності засобів; врахування закономірностей вікового локомоторного розвитку.

В підготовчій частині заняття, окрім гімнастичних вправ для різних груп м'язів, використовували оригінальний комплекс суглобової гімнастики 3 метою підготовки організму молодших школярів до виконання технічних елементів таеквон-до (табл.1). В основній частині заняття акцент робився на вивчення й удосконалення базових ударів ногами, а саме: ап оллігі - мах ногою вперед; ан оллігі - мах ногою зовні всередину; баккат оллігі - мах ногою зсередини назовні; ап-паль - удар спереду стоїть ногою; титпаль - удар ззаду стоїть ногою; ап-чаги - прямий удар ногою вперед; доліо-чаги - удар ногою збоку, бічний удар; пальбакко - зміна положення ніг; йоп-чаги - удар ногою убік, прямий удар; неріо-чаги - удар ногою зверху вниз; ті-двіт (твіт)-чагі - прямий удар ногою з розворотом; сево ан-чаги - удар ногою збоку великого пальця; хуріо (фуріо) чагі - круговий удар ногою; торн (тьо тіррени дора) доліо-чаги - бічний удар ногою 3 розворотом через спину (на $\left.180^{\circ}\right)$; миру-чаги - штовхає, прямий удар ногою [2].

Таблиия 1

Комплекс гімнастичних вправ для суглобів

\begin{tabular}{|l|l|l|l|}
\hline $\begin{array}{l}\text { № } \\
\text { з/п }\end{array}$ & \multicolumn{1}{|c|}{ Опис вправи } & $\begin{array}{l}\text { К-сть, } \\
\text { тривалість }\end{array}$ & Методичні вказівки \\
\hline \multicolumn{4}{|c|}{ Вправи для суглобів нижніх кінцівок } \\
\hline 1. & $\begin{array}{l}\text { В.п. о.с. Піднятися на пів пальці і плавно } \\
\text { перочучатися на п’яти і навпаки. }\end{array}$ & $8-10$ & $\begin{array}{l}\text { Виконувати рух повіль- } \\
\text { но, в повній амплітуді }\end{array}$ \\
\hline 2. & $\begin{array}{l}\text { В.п. стійка на правій/лівій нозі, інша нога } \\
\text { вперед. Кругові рухи стопою в одну і другу } \\
\text { сторону. }\end{array}$ & $5-10$ & $\begin{array}{l}\text { 3дійснювати 3 макси- } \\
\text { мально можливим зги- } \\
\text { нанням і розгинанням } \\
\text { стопи. }\end{array}$ \\
\hline
\end{tabular}




\begin{tabular}{|c|c|c|c|}
\hline & & & Продовження таол \\
\hline 3. & $\begin{array}{l}\text { В.п. сід. Перша фаза вправи. Максимально } \\
\text { розігнути стопи і утримувати } 4 \text { с, а потім зі- } \\
\text { гнути тільки пальці і теж фіксувати протягом } \\
4 \text { с. Друга фаза. Максимально зігнути стопу і } \\
\text { зафіксувати протягом } 4 \text { с, а після цього зро- } \\
\text { бити згинання в плесно-фалангових суглобах } \\
\text { (тримати } 4 \text { с). }\end{array}$ & $5-10$ & $\begin{array}{l}\text { Амплітуда рухів } \\
\text { максимально можлива. }\end{array}$ \\
\hline 5. & $\begin{array}{l}\text { В.п. стійка на одній нозі, друга вперед зігнута } \\
\text { в кульшовому і колінному суглобах. Кругові } \\
\text { рухи гомілкою в одну й іншу сторону. }\end{array}$ & $5-10$ & $\begin{array}{l}\text { Рухи виконувати } 3 \\
\text { максимальною } \\
\text { амплітудою. }\end{array}$ \\
\hline 6. & $\begin{array}{l}\text { В.п. о.с. Зігнути ногу (ліву/праву) в колінно- } \\
\text { му суглобі і зробити захват однойменною } \\
\text { рукою за стопу притискаючи ії до сідниць. }\end{array}$ & $15-30 \mathrm{c}$ & $\begin{array}{l}\text { Коліна притиснути } \\
\text { одне до одного. }\end{array}$ \\
\hline 7. & $\begin{array}{l}\text { В.п. Вузька стійка, ноги нарізно. Колові } \\
\text { обертання тазом праворуч і ліворуч. }\end{array}$ & $5-10$ & $\begin{array}{l}\text { Величину кола по- } \\
\text { ступово збільшувати. }\end{array}$ \\
\hline 8. & $\begin{array}{l}\text { В.п. о.с. Зігнути ногу в кульшовому і колін- } \\
\text { ному суглобах, зробивши захват двома рука- } \\
\text { ми за гомілку. }\end{array}$ & $15-30 \mathrm{c}$ & $\begin{array}{l}\text { Максимально притис- } \\
\text { нути стегно до живота. }\end{array}$ \\
\hline 9. & $\begin{array}{l}\text { В.п. сід. Півлотос (одна нога - права/ліва, } \\
\text { вперед, а друга зігнута в колінному суглобі і } \\
\text { притиснута стопою до стегна. }\end{array}$ & $30 \mathrm{c}$ & $\begin{array}{l}\text { Стопа п’ятою якомога } \\
\text { ближче до паху. }\end{array}$ \\
\hline 10. & $\begin{array}{l}\text { В.п. сід. Лотос. Згинаючи ноги в колінних } \\
\text { суглобах з’єднати стопи якомога ближче до } \\
\text { тазу. }\end{array}$ & $30 \mathrm{c}$ & $\begin{array}{l}\text { Долонями натискати на } \\
\text { стегна притискуючи їх } \\
\text { до площі опори. }\end{array}$ \\
\hline \multicolumn{4}{|c|}{ Вправи для суглобів верхніх кінцівок } \\
\hline 11. & $\begin{array}{l}\text { В.п. стійка, руки в сторони, пальці в кулак. } \\
\text { Колові рухи кистями. }\end{array}$ & $5-10$ & $\begin{array}{l}\text { Амплітуда } \\
\text { максимальна. }\end{array}$ \\
\hline 12. & $\begin{array}{l}\text { В.п. стійка права/ліва рука вперед долонею } \\
\text { від себе. Протилежною рукою зробити на- } \\
\text { тискання на тильну сторони стопи, забезпе- } \\
\text { чивши максимальне згинання у зап’ястку і } \\
\text { навпаки, зробивши захват за пальці забезпе- } \\
\text { чити максимальне розгинання в прменево-- } \\
\text { зап’ястному суглобі. }\end{array}$ & $10-20 \mathrm{c}$ & $\begin{array}{l}\text { Забезпечити макси- } \\
\text { мальне згинання і } \\
\text { розгинання. }\end{array}$ \\
\hline 13. & $\begin{array}{l}\text { В.п. стійка, руки в сторони. Обертання в лік- } \\
\text { тьових суглобах. }\end{array}$ & $5-19$ & $\begin{array}{l}\text { Амплітуда } \\
\text { максимальна. }\end{array}$ \\
\hline 14. & $\begin{array}{l}\text { В.п. Стійка, руки в сторони. Колові рухи } \\
\text { руками в плечових суглобах впред і назад. }\end{array}$ & $5-10$ & $\begin{array}{l}\text { Величину кола по- } \\
\text { ступово збільшувати. }\end{array}$ \\
\hline
\end{tabular}

На рис. 1 наведена демонстрація ділянок поверхонь стопи, які забезпечують ефективність ударів ногами. Це було обумовлено тим, що під час виконання ударів ногами стопа відіграє одну з головних функцій. В процесі занять значну увагу приділяли формуванню ударних поверхонь стопи за допомогою маківар, лап і падів.

Щодо заключної частини заняття, то основними засобами були релаксаційні вправи, дихальна гімнастика, вправи для розвитку гнучкості і самомасаж стопи і гомілки. Секційні заняття проводилися під керівництвом тренера-інструктора з таеквондо тричі на тиждень протягом 9-ти місяців, тривалістю 60 хвилин. Максимальна ЧСС не перевищувала 140 уд/хв. 


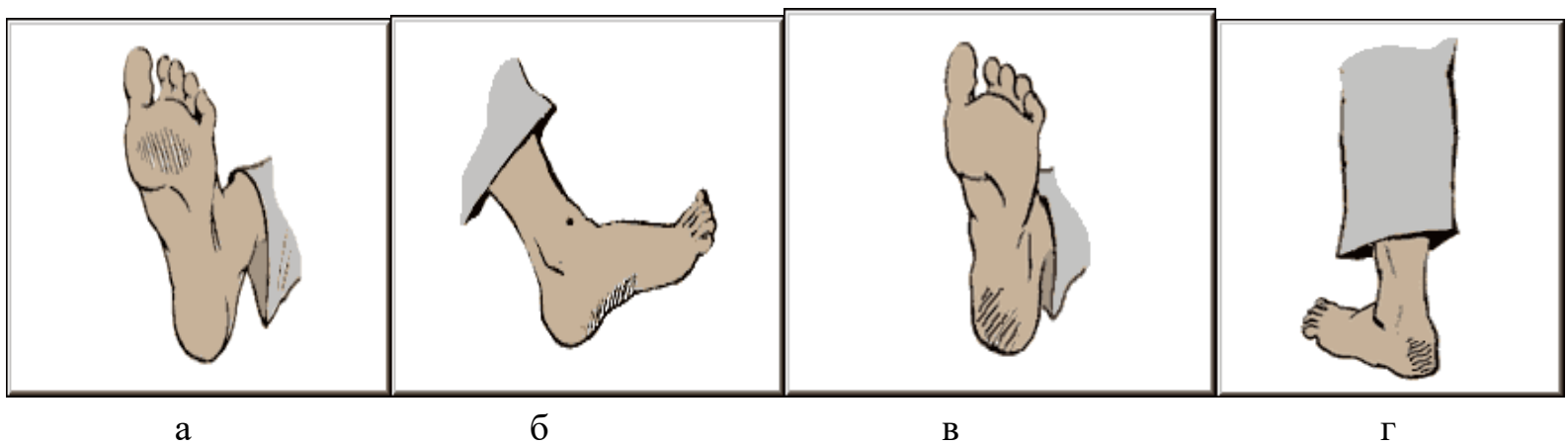

Puc. 1. Ударні поверхні стопи, що використовуються під час ударів ногами в таеквон-до: a - апчук (підстава пальців стопи); б - апчук (ребро стопи); в - бальналь дун (зворотне ребро стопи); двіткумчі (п’ята) [2].

Аналіз плантограм зроблених до початку педагогічного експерименту дозволив встановити розподіл дітей за ступенем плоскостопості. Зокрема встановлено, що 76,4\% хлопчиків мали I і 23.62\% - II ступінь плоскостопості. В результаті педагогічного експерименту відбулися вірогідні зміни щодо показників плантограми (табл. 3).

Зміна показників склепіння стопи у молодших школярів

Таблиия 3 після реалізації програми $(\mathbf{n}=\mathbf{2 5})$

\begin{tabular}{|c|c|c|}
\hline \multirow[t]{2}{*}{ Показники } & До початку занять & Через 9-ть місяців \\
\hline & $\mathrm{M} \pm \mathrm{m}$ & $\mathrm{M} \pm \mathrm{m}$ \\
\hline Коефіцієнт К & $1,4 \pm 0,06$ & $1,0 \pm 0,06^{*}$ \\
\hline СНСК (п'ятковий кут) & $-42^{0} \pm 1,8$ & $-19,0^{0} \pm 2,0^{*}$ \\
\hline СNAP (кут при I-му пальці) & $13,5^{0} \pm 2,3$ & $14,9^{0} \pm 1,3^{*}$ \\
\hline <QBR (кут при п’ятому пальці) & $11,0^{0} \pm 1,5$ & $7,7^{0} \pm 1,53^{*}$ \\
\hline
\end{tabular}

Примітка. * $-\mathrm{P}<0,05$.

Як видно з даної таблиці, відбулося зменшення коефіцієнту К до нормальних величин, а також зросли кути при першому і п'ятому пальцях та збільшився п'ятковий кут. Сукупність цих змін засвідчує нормалізацію склепінчастого апарату стопи.

При повторному тестуванні виявлено також вірогідне зростання $(9,5 \%, \mathrm{p}<0,05)$ кількості підйомів на пів пальці, що вказує на зростання структурно-функціонального потенціалу м'язів стопи і гомілки.

Дискусія. Як відомо, немовлята зазвичай народжуються з гнучкою плоскостопістю. На момент народження домінуючою видимою структурою в ділянці медіального краю підошовної дуги $\epsilon$ скупчення жирової тканини $[1,13]$. Протягом перших 10-ти років життя медіальний край поздовжньої арки ровивається разом із кістками, м'язами та зв'язками всередині стопи. До двох років у дітей розвивається медіальна арка і добре помітна в положенні сидячи. Вона може зменшуватися при зростанні навантаження на ногу і стопа набуває вигляду плоскої [12]. Не визначено, чи слід розглядати це як варіант норми чм як деформацію, що може призвести до майбутньої патології.

Незважаючи на значну поширеність, проблему плоскостопості часто тлумачать не зовсім коректно і це, очевидно, обумовлено відсутниністю єдиної системи класифікації щодо визначення дитячої плоскостопості.

Нормальний розвиток медіальної (внутрішньої) поздовжньої арки склепіння стопи може відбуватися протягом кількох років із широким спектром варіацій [4]. Наявність pes planus (плоских стоп) у дітей різного віку є доволі поширеним явищем [3]. 
При цьому, у дітей плоскостопість можна емпірично розділити на гнучку й жорстку. Основну увагу в цій статті приділено корекції гнучкої плоскостопості.

У різних дослідженнях пропонуються різні методи визначення плоскостопості, що базуються на відбитках підошви стопи, відношенні ширини п'яти й склепіння, суб'єктивній оцінці або даних рентгенографії [13]. Проте, найбільш доступним і доволі інформативним методом $є$ плантографія (отримання відбитків підошви стопи), який ми й використали в дослідженні [5].

На даний час жоден з факторів (недорозвинені м'язи стопи, слабкість м'язовозв'язкового апарату, надмірні фізичні навантаження, надлишкова вага, тривала гіпокінезія, неправильно підібране взуття, косолапість, ікс-подібна форма ніг, травми стопи та надп'ятковогомілкового суглобу, а також генетично детермінована форма стопи) не визнано основною причиною розвитку дитячої гнучкої плоскостопості $[1,5,6,8,13]$. Існують дві класичні теорії щодо етіології захворювання. Одна з них припускає, що гнучка плоскостопість $\epsilon$ результатом ослаблення м'язів стопи. Згідно з іншою, формування склепіння в основному залежить від форми й міцності кістково-зв'язкового комплексу. Останнє підтверджується спостереженням, що неспроможність п’ятково-човноподібної зв'язки є загальною ланкою при зникненні нормальної медіальної арки під час навантаження на ногу [13]. Зважаючи на ці міркування ми й використали таку сукупність засобів (таеквон-до, суглобову гімнастику), які мають найбільший вплив на структурні утворення стопи (кістки, м'язи, зв'язки). Як результат, досягнуто посилення структурно-функціонального потенціалу стопи, а відтак і нормалізацію іiі склепіння.

Висновок. Отже встановлено, що комплексне застосування засобів таеквон-до i суглобової гімнастики забезпечує нормалізацію склепінчастого апарату стопи у дітей молодшого шкільного віку з I-II ступенем плоскостопості.

1. Беленький АГ. Плоскостопие: проявления и диагностика. Consilium Medicum. 2005; 7(8): 14-21.

2. Бердышев СН. Боевые искуства. Философия и техника боя. Ростов-на Дону: ид-во Феникс, 2002. $496 \mathrm{c.}$

3. Жарова І. Ефективність застосування засобів фізичної реабілітації у хворих з порушенням опорнорухового апарату (остеохондроз і плоскостопість). Теорія і методика фізичного виховання і спорту. 2005; 2/3: 45-48.

4. Лосева ВС. Плоскостопие у детей 6-7 лет: профилактика и лечение. Москва: Сфера, 2004. 64 с.

5. Мартиросов ЭГ Методы исследований в спортивной антропологии. Изд-во: М.: Физкультура и спорт, 1982. 199 с.

6. Мохаммед Абдель Кадер Амро. Профілактика і лікування плоскостопості у дітей. Фізичне виховання в школі. 2000;1: 42-46. 52.

7. Мохаммед Абдель Кадер Амро. Динаміка показників дослідження стопи і фізичного розвитку дітей 3 плоскостопістю у період реабілітації. Теорія та методика фізичного виховання і спорту. 2001; 3: 66-69.

8. Очерет АА. Как жить с плоскостопием. М.: Советский спорт. 2000. 96 с.

9. Христова Т, Казакова С, Казаков С. Фізична реабілітація дітей дошкільного віку з функціональною недостатністю стопи. Спортивний вісник Придніпров'я. 2012; 3: 114-116. URL: http://nbuv.gov.ua/ UJRN/svp_2012_3_27.

10. Герасимова ГН., Павлычева ЛА. Возрастные изменения опорно-двигательного аппарата и их связь с развитием двигательных качеств. Москва, 2001. 355 с.

11. Альошина А, Бичук I. Технологія профілактики плоскостопості дітей старшого дошкільного віку засобами фізичної культури. Вісник Прикарпатського університету. Серія: Фізична культура. 2012; 16: 126-135.

12. Mitova S, Popova D, Gramatikova M. Flat foot in children and growing up - actual problem. Research in Kinesiology. 2015; 43 (1): 25-27.

13. Carr JB, Yang S, Lather LA. Pediatric Pes Planus: A State-of-the-Art Review. Pediatrics. 2016 ; 137 (3): e20151230. 


\section{References}

1. Belenkyi AH. (Ploskostopye: proiavlenyia y dyahnostyka. Sonsilium Medicum. 2005; 7( 8): 14-21.

2. Berdushev SN. Boevыe yskustva. Fylosofyia y tekhnyka boia. Rostov-na Donu: yd-vo Fenyks, 2002. $496 \mathrm{~s}$.

3. Zharova I. () Efektyvnist zastosuvannia zasobiv fizychnoi reabilitatsii u khvorykh z porushenniam opornorukhovoho aparatu (osteokhondroz i ploskostopist). Teoriia i metodyka fizychnoho vykhovannia i sportu. $2005 ; 2 / 3: 45-48$.

4. Loseva VS. (2004) Ploskostopye u detei 6-7 let: profylaktyka y lechenye. Moskva : Sfera. 64 s.

5. Martyrosov ЭН. Metodы yssledovanyi v sportyvnoi antropolohyy. Yzd-vo: M.: Fyzkultura y sport, 1982. $199 \mathrm{~s}$.

6. Mokhammed Abdel Kader Amro. Profilaktyka i likuvannia ploskostoposti u ditei. Fizychne vykhovannia v shkoli. 2000; 1: 42-46, 52.

7. Mokhammed Abdel Kader Amro. Dynamika pokaznykiv doslidzhennia stopy i fizychnoho rozvytku ditei z ploskostopistiu u period reabilitatsii. Teoriia ta metodyka fizychnoho vykhovannia i sportu. 2001; 3: 66-69.

8. Ocheret AA. Kak zhyt s ploskostopyem. M.: Sovetskyi sport. 2000. $96 \mathrm{s.}$

9. Khrystova T, Kazakova S, Kazakov Ye. Fizychna reabilitatsiia ditei doshkilnoho viku z funktsionalnoiu nedostatnistiu stopy. Sportyvnyi visnyk Prydniprovia. 2012; 3: 114-116. Rezhym dostupu: http://nbuv. gov.ua/UJRN/ svp_2012_3_27.

10. Herasymova HN, Pavlucheva LA. Vozrastnue yzmenenyia oporno-dvyhatelnoho apparata y ykh sviaz s razvytyem dvyhatelnukh kachestv. Moskva, 2001. 355 s.

11. Aloshyna A, Bychuk I. Tekhnolohiia profilaktyky ploskostoposti ditei starshoho doshkilnoho viku zasobamy fizychnoi kultury. Visnyk Prykarpatskoho universytetu. Seriia: Fizychna kultura. 2012; 16: 126-135.

12. Mitova S, Popova D, Gramatikova M. Flat foot in children and growing up - actual problem. Research in Kinesiology. 2015; 43 (1): 25-27.

13. Carr JB, Yang S, Lather LA. Pediatric Pes Planus: A State-of-the-Art Review. Pediatrics. 2016; 137 (3): e20151230.

Цитування на цю статтю:

Випасняк ІП, Мицкан БМ, Мицкан ТС, Войчишин ЛІ. Корекція порушень склепінчастого апарату стопи у молодших школярів засобами таеквон-до. Вісник Прикарпатського університету. Серія: Фізична культура. 2020 Листоп 24; 36: 101-107

\begin{tabular}{|c|c|}
\hline Відомості про автора: & Information about the author: \\
\hline $\begin{array}{l}\text { Випасняк Ікор Петрович - доктор наук з фізич- } \\
\text { ного виховання с спорту, професор, ДВНЗ “При- } \\
\text { карпатський національний університет імені Васи- } \\
\text { ля Стефаника" (Івано-Франківськ, Україна) }\end{array}$ & $\begin{array}{l}\text { Vypasnyak Ihor Petrovych - Doctor of Science in } \\
\text { Physical Education and Sports, Professor, Vasyl } \\
\text { Stefanyk Precarpathian National University (Ivano- } \\
\text { Frankivsk, Ukraine) }\end{array}$ \\
\hline \multicolumn{2}{|l|}{$\begin{array}{l}\text { e-mail: kicuk80@gmail.com } \\
\text { https://orcid.org/0000-0002-4192-1880 }\end{array}$} \\
\hline $\begin{array}{l}\text { Мицкан Богдан Михайлович - доктор біологічних } \\
\text { наук, професор, завідувач кафедри теорії та мето- } \\
\text { дики фізичної культури і спорту, ДВНЗ “Прикар- } \\
\text { патський національний університет ім. Василя Ст- } \\
\text { фаника” (Івано-Франківськ, Україна) }\end{array}$ & $\begin{array}{l}\text { Mytskan Bohdan Mykhailovych - Doctor of Bio- } \\
\text { logical Science, Professor, Head of Chair of Theory } \\
\text { and Methods of Physical Training and Sports, Vasyl } \\
\text { Stefanyk Precarpathian National University (Ivano- } \\
\text { Frankivsk, Ukraina) }\end{array}$ \\
\hline \multicolumn{2}{|l|}{$\begin{array}{l}\text { e-mail: bogdanmytskan21@gmail.com } \\
\text { https://orsid.org/0000-0002-5853-713X }\end{array}$} \\
\hline $\begin{array}{l}\text { Мицкан Тетяна Степанівна - кандидат психоло- } \\
\text { гічних наук, доцент, ДВНЗ “Прикарпатський на- } \\
\text { ціональний університет імені Василя Стефаника" } \\
\text { (Івано-Франківскк, Україна) }\end{array}$ & $\begin{array}{l}\text { Mytskan Tetiana Stepanivna - Candidate of Science } \\
\text { (Psychology), Associate Professor (Ph. D.), Vasyl } \\
\text { Stefanyk Precarpathian National University (Ivano- } \\
\text { Frankivsk, Ukraine) }\end{array}$ \\
\hline \multicolumn{2}{|l|}{$\begin{array}{l}\text { e-mail: tania_mytskan@ukr.net } \\
\text { http://orcid.org/0000-0002-4164-2961 }\end{array}$} \\
\hline $\begin{array}{l}\text { Войчишин Лілія Ігорівна - кандидат наук з фізич- } \\
\text { ного виховання і спорту, доцент, ДВНЗ "Прикар- } \\
\text { патський національний університет імені Василя } \\
\text { Стефаника" (Івано-Франківськ, Україна) }\end{array}$ & $\begin{array}{l}\text { Voychyshyn Liliya Ihorivna - Candidate of Science } \\
\text { (Physical Education and Sport), Associate Professor } \\
\text { (Ph.D.) Vasyl Stefanyk Precarpathian National Uni- } \\
\text { versity (Ivano-Frankivsk, Ukraine) }\end{array}$ \\
\hline & \\
\hline
\end{tabular}

